\title{
Chasing for water monitors using dogs in West Java, Indonesia: a recreational hunting or pest control?
}

\author{
Andhika Prima Yudha ${ }^{1 *}$, Mirza Dikari Kusrini ${ }^{2}$, Evy Arida $^{3}$
}

\begin{abstract}
Wildlife hunting for subsistence is mostly reported in rural areas and performed by traditional people. Whereas it is also practiced in urban areas and targeted for abundant urban species such as the. water monitor (Varanus salvator). Urban hunting may be linked to pest control or pastime activity, which could be beneficial for wildlife management. Our purpose of study was to investigate hunting practice of water monitor in Bogor area, West Java, Indonesia. Data was collected between January and June 2020 to find characteristics and motivation of hunters, their hunting methods, and harvests. We were able to conduct face-to-face interviews with 42 local urban people, whom we followed in four hunting groups during their search for wildlife. Generally, hunters were students, workers, or laborers, who hunt only during the weekends. To capture water monitors, some hunters used dogs and air rifles, while some others used nothing but bare hands. During our observation, 157 individual water monitors were targeted, but only 150 were caught. There were several motivations for hunters to target water monitors apart from being a hobby, i.e., for food and to eliminate pest. Due to its motivation and strategy, we consider the hunt for water monitor in Bogor area mainly for recreational purposes.
\end{abstract}

Keywords: Air rifle; Bogor; Dogs; Dobby hunters; Lizard.

\footnotetext{
1 Department of Forest Resources Conservation \& Tourism, Faculty of Forestry \& Environment, IPB University, Kampus Dramaga, Bogor, 16680, Indonesia.

2 Contact Person. Department of Forest Resources Conservation \& Tourism, Faculty of Forestry \& Environment, IPB University, Kampus Dramaga, Bogor, 16680, Indonesia.

3 Museum Zoologicum Bogoriense (MZB), Pusat Penelitian Biologi, Lembaga Ilmu Pengetahuan Indonesia (LIPI), Jalan Raya Bogor-Jakarta Km.46, Cibinong 16911, Indonesia..

* Corresponding author $\bowtie$. E-mail address: APY (adhkaydha@gmail.com), MDK (mirza_kusrini@yahoo.com), EA (evya001@lipi.go.id)
}

\section{SIGNIFICANCE STATEMENT}

Our research on the hunt of water monitors in an urban area is one of the rare ethnozoological studies of commonly used reptile species in Indonesia. The resulting knowledge of our study adds into the current understanding on the utilisation of reptiles, particularly the water monitor. In the end, our data will be useful for planning population management of the species, especially if conflicts between human and water monitor are increasing. 


\section{INTRODUCTION}

Wildlife is considered common resource by traditional communities around the world (Bennett and Robinson 2000; Naranjo et al. 2004; Obioha et al. 2012). Subsistence hunting is important to ensure food security for local communities that live near the forest (Nasi et al. 2011; Pangau-Adam et al. 2012; Pattiselano and Lubis 2014). Target species are being hunted for their meat, skins, and medicinal purposes, but also as a defense mechanism (Alves et al. 2018).

Wildlife hunting was originally a sustenance for local communities, but in the recent years it has shifted to become the main option for economic income of rural communities in various developing countries (Duffy et al. 2016; Robinson et al. 2018). The shift of subsistence hunting to commercial hunting has increased the number of wild animals being caught due to the use of modern hunting tools (Dounias 2016). On the other hand, recreational hunting, for which motivational background is pleasure (LeaderWilliams 2009), is increasingly enjoyed especially in the developed countries (Di Minin et al. 2021; Sharp and Wollscheid 2009). In a broader sense, recreational hunting includes trophy hunting, sports hunting, and tourism hunting, (Leader-Williams 2009) and often involved big mammals (Dickson et al. 2009), as well as small game such as birds (Fernandes-Ferreira et al. 2012).

Harvested wildlife as a result of hunting are traded as raw or processed products to other communities, sometimes also crossing national borders, and in the end contributing to national income (Scheffers et al. 2019; Hierink et al. 2020). Reptiles are among the most-hunted groups of animals and harvested for meat consumption, skin, medicinal purposes, or taken alive for pets (Marshall et al. 2020; Scheffers et al. 2019; Nijman et al. 2012). The water monitor, Varanus salvator is one of the most exploited species of monitor lizards (King and Green 1999; Pernetta 2009). The large-sized lizard species is distributed throughout southern and Southeast Asia and often found in various habitats, including those disturbed by humans. Despite large levels of harvesting, populations are still abundant in some parts of its range (Gaulke and Horn 2004).

Reports on the use of water monitors in Indonesia is mostly for exports. Most international trades of this species were sourced from the islands of Sumatra, Sulawesi, and Kalimantan (Mardiastuti and Soehartono 2003). The water monitors are included in the Appendix II of Convention of International Trade in Endangered Species of Wild Fauna and Flora (CITES), which means that this species may be threatened to extinction if trade continues unregulated (Mardiastuti and Soehartono 2003). Some reports on this species discussed aspects of its reproductive biology in relation to sustainability of harvest (Shine et al. 1996; 1998) as well as local consumption in North Sumatra (Arida et al. 2020) and West Java (Herzegovina et al. 2021). Reports on this species often implied commercial motivations (Nijman 2015; Herzegovina et al. 2021) but see Uyeda (2015) for reporting on predation of water monitors on poultry.

Wildlife hunting is generally reported as traditional and rural community activity for subsistence (Fa et al. 2002; Riley 2002; Pattiselanno et al. 2010; Lupo 2011; Farida et al. 2014; Pangau et al. 2012; Pattiselanno et al. 2014; Latinne et al. 2020). Reports on urban hunting is scarce (e.g., van Vliet et al. 2015) and there is no detailed report to be based on urban communities in Indonesia. In this study, we report urban hunting in Bogor, a town directly adjacent to the national capital of Jakarta, which is known as the main hub of national wildlife trade in Indonesia (Morgan 2016). Details on the characteristics of hunters, their motivational background, hunting methods, and yields of harvest are presented as evidence of urban hunting prevailing in West Java. Our results are aimed to inform wildlife managers on the non-commercial utilisations of water monitor in urban areas.

\section{MATERIAL AND METHODS}

Data was collected in the Bogor area, including the City of Bogor. Hunting and trading activities of reptiles were reported to occur in 11 out of 40 districts in Bogor regency (Situngkir 2009). Our surveys were carried out around the districts of Dramaga, Ciampea, Cibinong, Cibungbulang, Cijeruk, Tajur Halang Cileungsi, Ciomas, Ciseeng, Jasinga, Leuwiliang, Jonggol, and Parung (Figure 1).

Using snowball sampling (Padam et al. 2007), hunters were succesfully identified among the general public. A hunting group was initially encountered around IPB University Campus in Dramaga, Bogor, with whom APY was allowed to join in a hunting trip. Based on some information obtained from members of this group, we were able to conduct face-to-face interviews with 42 local hunters during the period between January and June 2020. Our questionnaires were designed to gather information on the characteristics of hunters (e.g., place of residency, age, and occupation), hunting methods (i.e., in groups vs single-person, motivations of hunting, and duration of hunting).

We followed hunters during their hunting trips and marked their locations using GPS tracking, in order to determine travel distance and period of hunting. We noted hunters' equipments and the number of water monitors caught in one trip. Every water monitor caught by hunters in one trip was measured for their 


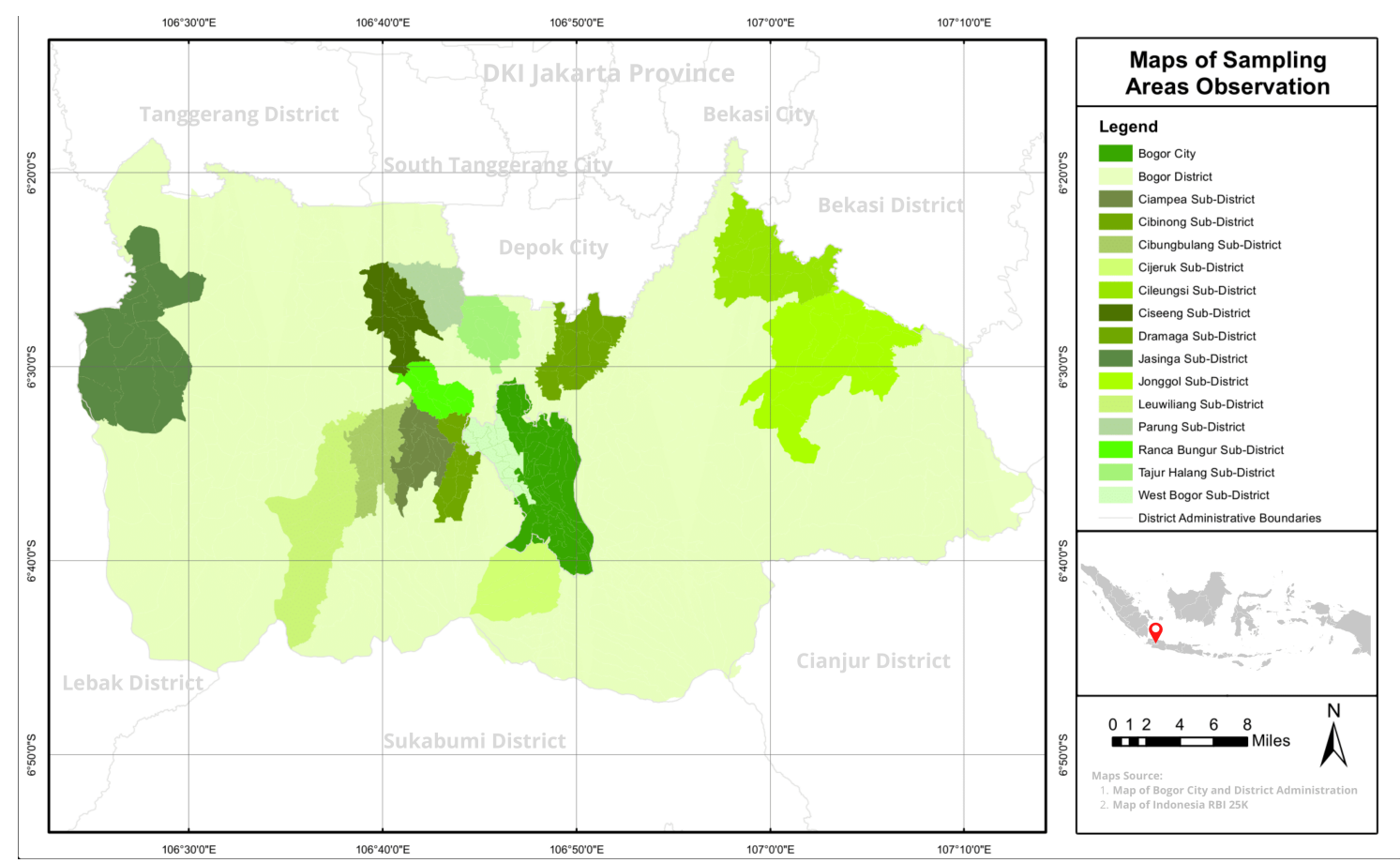

Figure 1. Maps of Bogor location as sampling areas observation.

total length, Snout-Vent length (SVL), tail length, and mass (Shine et al. 1998). Sex determination for harvested lizards was done by pressing the cloaca for male genitalia or called "hemipenes" (Sabarno 2012). Lizards with SVL less than $35 \mathrm{~cm}$ is determined a juvenile.

\section{RESULTS}

\section{Characteristics and motivations of hunters}

Our interviewees were all hunters of young age. The youngest hunter was 15 years-old and the oldest was 35 years-old. Twenty-five of these hunters (52\%) were students and 17 people $(35.4 \%)$ worked in several sectors. These hunters worked in groups called "pasmor", which stands for "Pasukan Moro" (hunting troops). "Moro" means "to hunt" in Sundanese, which is the dominant ethnic in Bogor. There were four groups of hunters in our study (Table 1) and each group went for a hunt independently. Most members of hunting groups came from the same village and they knew each other, although some came from different villages, where hunting for water monitor was considered a negative activity. In this case, hunting for water monitor was thought non-profitable and a waste of time. Information on the whereabouts of these groups were passed on by words of mouth, as well as through social medias. Thus, it was relatively easy to search for and found these groups in facebook or instagram using the keyword "pasmor".

During a hunting session, the number of people in one Pasmor varied from eight to 12. Generally, the total number of members in each Pasmor may reach 50 people. Most hunters $(50 \%)$ have a motivation of leisure, including meat consumption and oil use from the fat. About one-third (33.3\%) of our respondents consider hunting as a hobby, which has a side effect of pest eradication and subsequent protection of their livestocks. Poultry is primarily the livestock of villagers in Bogor. Around $10 \%$ of hunters said they sold their catch of adult water monitors in the form of meat for medicinal purposes and juvenile animals were sold as pets. The methods of sale includes customer pre-order, direct buy at the hunter's house, and social media advertisment. Only a small proportion of hunters $(7.14 \%)$ were motivated to catch water monitor solely for pets, in this case they target small size lizards.

\section{Hunting methods}

Members of hunting groups usually gather in the morning at a neighborhood watch post, traditional food stalls (warung), or at an agreed location to discuss equipments, time and place of starting points, hunting locations, and transportations. The discussions were followed up using smartphones through a communication application to inform other members 
Table 1. Average distance and duration of a hunting session during March 7 - June 28, 2020.

\begin{tabular}{lccccc}
\hline \hline Group Name & N & $\begin{array}{c}\text { Mean + SD } \\
\text { length of track } \\
(\mathbf{k m})\end{array}$ & $\begin{array}{c}\text { Range of } \\
\text { route }(\mathbf{k m})\end{array}$ & $\begin{array}{c}\text { Mean + SD } \\
\text { of work duration } \\
\text { (Minute) }\end{array}$ & $\begin{array}{c}\text { Range } \\
\text { duration } \\
\text { (minute) }\end{array}$ \\
\hline \hline Pasmor 96 & 16 & $12.62+11.17$ & $2.18-40.40$ & $313.13+114.88$ & $120-480$ \\
Pasmor Dm86 & 16 & $13.29+11.82$ & $4.07-40.40$ & $277.50+117.73$ & $120-420$ \\
Pasmor Camp Java & 8 & $9.6+7.03$ & $0.38-19.24$ & $386.25+114.88$ & $180-540$ \\
Pasmor Carpoel Pojok & 8 & $7.08+3.63$ & $2.18-13.98$ & $318.75+102.60$ & $180-420$ \\
Total & 48 & $11.49+9.96$ & $314.38+119.19$ & & \\
\hline \hline
\end{tabular}

of the group on the time and location of the gathering.

Hunters used a four-wheel drive vehicle or a pickup car to reach locations far from their homes. The group rents a car or city transportation and each person paid US\$ 0.69 (IDR 10,000). Because most of the hunters are students relying on their parents' financial support, nearby areas were chosen to enable a hunt on foot or the use of personal motorbikes. Therefore, preferred hunting locations were the riverbanks close to their homes. As suitable habitats are available in the IPB University campus in Darmaga, Bogor, this location is one of the favourite areas for hunting water monitors. More senior hunters who earn an income usually hunt in locations far from their homes because they can pay for their own transportation. Hunting sessions are generally started between 09:00 and 16:00 during a weekend. Hunters did not carry food or water supplies because they were considered impractical. Instead, hunters collected fruits along their hunting route from the villagers' gardens, for example guavas, papayas, and coconuts.

A hunting session might be delayed if the person to handle the dogs or the most skilled hunters were unwell. Weather is also an important factor for a hunting session to succeed. In the event of rain, hunters could cancel their planned session for fear of lightning strikes. As locations for a hunting session is generally close to a river, rain and flooding is also a condition that hunters tend to avoid. Group members met at a designated location and headed straight to a hunting location along the river on foot. If there were many members joining a hunt, the group split into small groups of 2 to 3 people, in order to simplify their action for capture. After spotting the animal in a certain location, the two to three people positioned themselves to surround the target animal and limit its movement for flight.

Hunting permit was unnecessary for these villagers, who were basically poor and catch unprotected wildlife such as water monitors with trivial motiva- tions. Casual daily clothings (i.e., shorts and T-shirts) and footwears (e.g., sandals) were used by hunters instead of special protective clothing for field work such as coverall. Three to five dogs were used as helpers in the search team in each hunting event. These dogs were called as "perbituran". Humans and dogs moved actively, walking and searching for water monitors in the thickets of vegetation, rice fields, human settlements, and along steep river cliffs. Average hunting duration was $314.38 \pm 119.19$ minutes (about 5.25 hours) and depending on the terrain being traveled. Average distance traveled was $11.49 \pm 9.96 \mathrm{~km}$ with (Table 1).

Water monitors were captured using a combination of methods that includes hunting dogs, air rifles, and bare hands. Hunters in charge of handling the dogs directed the dogs to search for water monitors and let the dogs to roam around the riverbanks unleashed. Upon finding a water monitor, the dogs alerted its master hunter by barking and chased down the lizard to herd it towards the hunter.

If a water monitor appeared on a tree canopy, hunters used an air rifle to shoot the lizard. The shooter is a specialised hunter who is not responsible to capture the fallen lizard. Up to three air rifles of mostly $4.5 \mathrm{~mm}$ calibre were available with a Pasmor. The use of air rifles is limited in the vicinity of hunters' village. This type of weapon is available for sale in limited number, whereas firearms are illegal for use by civilians. When air rifle is unavailable during a session, hunters captured the lizard using bare hands or throwing stones and wood to beat the lizard.

All the dogs used to help hunting were trained, usually when they were young, i.e two to four monthsold. The dogs are mostly crossbreed between mongrel and imported breeds obtained from the towns in West Java such as Bandung, Garut, and Sukabumi as well as those across the island on Sumatra. These dogs received special training and attention from owners, who gave extra fooding such as duck eggs, raw meat, 
and milk. The duration of dog training varies from four to 12 months. In order to exert their hunting skills, untrained dogs were sent directly to hunting ground with those already trained for wildlife hunting. Hunters gave direction to his dogs using words such as "ka dieu-ka dieu" (Sundanese for "come here, come here") while pointing at an object. However, some hunters prefer to buy trained dogs instead of training their helpers themselves.

During observations, a total of 157 water monitor were found, but seven were not captured. Of the 157 individuals, 61 individuals were caught using a combination of trained dogs, air rifles and bare hands. Table 2 shows that almost $97 \%$ of sightings was due to the help of dogs. Hunters found only a few water monitors when only air rifles were used and without the help of their dogs (Table 2).

Harvested lizards were tied off with raffia string around the pairs of front and hind limbs. A piece of wooden or bamboo stick was put between the pairs of legs for hunters to lift and carry the lizard to an agreed meeting point. The groups scored each of their catch as one point, for example a harvest of three lizards means three points. Medium sized lizards are sometimes kept alive, but those relatively large often killed for its meat. The meat is grilled on skewers ("sate") and enjoyed by the group members together.

In addition to water monitors, hunters also caught other species of reptile and mammals. Three reticulated pythons (Malayophyton reticulatus), five Asian palm civets (Paradoxurus hermaphroditus), one Asian mongoose (Herpestes javanicus), and eight otters ( $L u$ tra sp.) were caught during our observations. The animals are often sold for a high price. Otherwise, hunters keep them as pet or consume the meat, such as in the case of civets and otters caught during the observed sessions

\section{Characteristics of harvest}

There is no size limit in water monitor harvest in Bogor. All age classes of water monitor are targets for hunters. Of the 150 individuals caught, 70\% were adult males, $26 \%$ were adult females, and the rest was juveniles (Table 3). Mean SVL of males was smaller than that of females $(\mathrm{t} 142=3.837, \mathrm{P}<0.05)$. In average, male SVL was $47.63 \pm 4.89 \mathrm{~cm}$, whereas mean SVL for females was $51.27 \pm 5.49 \mathrm{~cm}$. Mean body weight of males was significantly (t142 $=5.145$, $\mathrm{P}<0.05)$ smaller $(3.37 \pm 0.77 \mathrm{~kg})$ than that of females $(4.33 \pm 1.41 \mathrm{~kg})$.

\section{DISCUSSION}

Wildlife hunting is often practiced for survival and to the point of being basic necessity in rural areas.
Generally, it aims to meet the economic needs of the community (Heberlain et al. 2008; Pattiselanno et al. 2010; Arida et al. 2020) and might be related to areas with good access (Latinne et al. 2020). Daily meat consumption may also be supplied from harvested game, especially when sales of domesticated animal is rare (van Vliet et al. 2015). However, the objective of wildlife hunting often shifts into a culture, in which harvests are not for self-consumption (Gustaman 2019; Rominto and Barlian 2019). Our case of water monitor hunting in Bogor does not seem to fall in the category of subsistence hunting or commercial hunting because monetary gain is small and the resulting harvest is unlikely to improve the economy of the hunters and their families. This hunting in urban area is also not aimed at supplying daily meat consumption, because livestocks are easily available in Bogor.

Most of our respondents (83\%) mentioned that their motivation for wildlife hunting is mainly for a pastime and hobby, although they justified their statements with more benefit-oriented reasons such as the use of meat and oil for health or a good deed of controlling pests. The Bogor hunters are not professionals such as those in North Sumatrea (Arida et al. 2020). These young people do not consider their activity as a part-time job, for example those specialising in snake hunting in Bogor (Situngkir 2009) or frog hunting in West Java (Kusrini and Alford 2006). The earlier generations most probably have taught these young people about pest eradication, but it develops slowly into an organised communal activity, even when the benefits for income is negligible. Such organised eradication program that evolves into a recreational activity was also reported for wild boars hunting in West Sumatra (Kasman 2014; Hidayati 2017; Seprianto 2019).

The hunts for water monitor in Bogor are a recreational activity, of which hunters are mostly youngsters and students, who organise their sessions only during the weekends or holidays. They used minimum equipments and transportation, i.e., walking the trail as part of weekend outdoor activities. These local people do not need any license or fee for their activity and unlike trophy hunting by urban dwellers in Spain who hunt far from their hometown as tourism activity (Matin-Delgado et al. 2020). However, older hunters might be willing to pay for their transportations to go to places farther, probably even joining some commercial hunting groups.

The young hunters think that hunting is enjoyable and has a positive effect, i.e., building social interactions, strengthening friendships, and mental sharpening. The activity is also about nature exploration and physical exercise. During our observations, the town of Bogor was one of those restricted for trav- 
Table 2. Number of water monitor sightings during hunting sessions in Bogor based on the use of dogs.

\begin{tabular}{lccc}
\hline \hline Group Name & Without dogs & With dogs & Total \\
\hline \hline Pasmor 96 & 0 & 52 & 52 \\
Pasmor Dm 86 & 0 & 31 & 31 \\
Pasmor Camp Java & 0 & 49 & 49 \\
Pasmor Carpoel Pojok & 5 & 20 & 25 \\
Total & 5 & 152 & 157 \\
\hline \hline
\end{tabular}

Table 3. Body conditions and sizes of harvested water monitors in Bogor.

\begin{tabular}{lccccccc}
\hline \hline $\begin{array}{l}\text { Variabel } \\
\text { Male }\end{array}$ & N & Range & Min & Max & Mean & SD & Variance \\
\hline \hline Weight (kg) & 105 & 3.80 & 1.30 & 5.10 & 3.37 & 0.77 & 0.60 \\
SVL (cm) & 105 & 21.50 & 35.00 & 56.50 & 47.63 & 4.89 & 24.00 \\
Tail length (cm) & 105 & 43.10 & 32.80 & 75.90 & 59.17 & 8.60 & 74.09 \\
Female & & & & & & & \\
Weight (kg) & 39 & 5.60 & 2.30 & 7.90 & 4.33 & 1.41 & 1.99 \\
SVL (cm) & 39 & 20.80 & 43.50 & 64.30 & 51.27 & 5.49 & 30.23 \\
Tail length (cm) & 39 & 52.80 & 53.00 & 105.80 & 67.31 & 11.85 & 140.46 \\
Juvenile & & & & & & & \\
Weight (kg) & 6 & 0.40 & 0.90 & 1.30 & 1.08 & 0.16 & 0.02 \\
SVL (cm) & 6 & 3.20 & 27.00 & 30.20 & 28.76 & 1.27 & 1.62 \\
Tail length (cm) & 6 & 10.10 & 30.10 & 40.20 & 35.56 & 3.63 & 13.22 \\
TOTAL & 150 & & & & & & \\
\hline \hline
\end{tabular}

els and daily activities due to the Covid-19 pandemic; however, hunting groups were actively searching for wildlife as an outlet to alleviate stress. By keeping scores on the number of water monitor captured, the groups were competing in playful mode.

Consumption of water monitor by people in West Java has been reported previously (Nijman 2016; Arida et al. 2021). Although the majority of people in Bogor are Muslims, it seems that hunters have no objection to eating parts of water monitor. Water monitor meat is favoured by several ethnicities in Indonesia (Luxmoore and Groombridge 1990; De Lisle 2007; Uyeda et al. 2014; Arida et al. 2020) and thought as medicines by people in areas of western Java, (Uyeda et al. 2014; Arida et al. 2021).

All hunters in Bogor were males. Traditionally, hunting is practiced by males in many parts of the world (Smith 1976). However, rural women occa- sionally hunt for small-sized mammals and reptiles (Heberlain et al. 2008; McElwee, 2012). They used dogs to help them hunting, similar to wild boar hunting in West Sumatra (Kasman 2014; Seprianto 2019) and in many other parts of the world (Koster 2008, 2009; Koster and Noss 2014). Hunting with the help of dogs has been practiced since prehistoric times (Lupo 2011) because dogs are known for their ability to detect the presence of dangers, such as poisonous snakes (Clagget 1998). Dogs are also useful to detect presence of cryptic wildlife such as (Nussear et al. 2008; Kapfer et al. 2012).

Hunters encountered water monitors more frequently with helps of dogs than without. The use of air rifles to shoot water monitors is an additional technological approach to ensure capture of the animals. Water monitors sometimes position themselves in a high tree canopy, which is out of direct human 
reach. Thus, combining the use of dogs and air rifle become an important method for the hunters to capture an agile wildlife such as water monitor. More specifically, talented trained dogs that have spent long enough time interacting with humans are those optimally helpful for hunting (Hare and Tomasello 2005) and thus given better treatments (Kostar 2008).

The catch of water monitors in Bogor is of similar average size compared to those in South and North Sumatra for commercial purposes (Shine et al. 1996; Arida et al. 2020). Size limit is not imposed for captures of water monitors in Bogor, which is opposite to commercial captures in North Sumatra aiming for adult lizards (Arida et al. 2020).

Recreational hunting is considered unethical with no benefit for local people (Di Minin et al. 2021). Over harvesting is also a negative impact that might be caused by hunting and create the empty forest syndrome (Benítez-López et al. 2017, 2019; Ripple et al. 2016; Peres 2000). We consider water monitor hunting in Bogor as non- commercial and is practiced by locals as a pastime activity. Hunting capacity of these urban young people are limited by time and strategy. Therefore, it is unlikely that their activity is enough to reduce water monitor population in the area. Water monitor population size in Bogor is apparently large, as the species is easily adapted to urban habitats. However, recreational hunting for water monitor might need to be regulated in the future, if this activity would develop into popular pastime resulting in unsustainable harvests. Further study may be necessary, as our study is in a preliminary stage of a larger study encompassing many other parts of West Java and other locations in Indonesia.

\section{CONCLUSION}

Our observations and analysis direct our view on the hunts for water monitor in Bogor, West Java as recreational in its nature. The young hunters casually look for wildlife, including water monitors, for the sake of doing some activity with friends during their free times around the neighborhoods. This type of hunting is not profitable and has little, if any, impact on populations of water monitors. At the same time, the species is adaptive to urban areas and some population management might be necessary for this common lizard. Nevertheless, we believe that hunters' additional motivations such as pest control and the search for medicines from water monitor meat are simply their way of justifying their favorite pastime.

\section{ACKNOWLEDGEMENT}

We thank Pasmor communities for being cooperative during interviews and helpful information on their hunting routines. We are also grateful to Daniel Natusch for his advice and review, as much as we appreciate three anonymous reviewers, who provide us with critical comments for us to improve our manuscript.

\section{DATA AVAILABILITY}

Data for our study will be made available upon reasonable request to the corresponding author.

\section{CONFLICT OF INTEREST}

The authors declare that there is no conflicts of interest.

\section{CONTRIBUTION STATEMENT}

MDK conceived the research idea; APY led the fieldwork; MDK, APY, EA carried out data analeses; APY wrote the initial draft of manuscript; EA reviewed and wrote the final manuscript; EA, MDK supervised the research project.

\section{REFERENCES}

Alves RRN, Souto WMS, Fernandes-Ferreira H, Bezerra DMM, Barboza RRD, Vieira WLS (2018) The Importance of Hunting in Human Societies. In: Ethnozoology: Animals in Our Lives, Elsevier, pp. 95-118.

Arida E, Hidayat A, Mulyadi, Maireda NL, Mumpuni (2020) Consumption and Trade of Asian Water Monitor, Varanus salvator as Reliance on Wildlife for livelihoods among Rural Communities in North Sumatera, Indonesia. Journal of Tropical Ethnobiology 3: 81-92.

Bennett EL, Robinson JG (2000) Hunting of wildlife in tropical forest: implications for biodiversity and forest peoples. Washington DC, USA, World Bank and WCS.

Benítez-López A, Santini L, Schipper AM, Busana M, Huijbregts MAJ (2019) Intact but empty forests? Patterns of hunting-induced mammal defaunation in the tropics. PLoS Biol 17: e3000247.

Benítez-López A, Alkemade R, Schipper AM, Ingram DJ, Verweij PA, Eikelboom JAJ, Huijbregts MAJ (2017) The impact of hunting on tropical mammal and bird populations. Science 356: 180-183. 
Claggett PR (1998) The spatial extent and composition of wildlife harvests among three villages in the Peruvian Amazon. Paper presented at the annual meeting of the Latin American Studies Association, Chicago, USA.

De Lisle HF (2007) Observations on Varanus s. salvator in North Sulawesi. Biawak 1: 59-66.

Direktorat Jenderal Perlindungan Hutan dan Konservasi Alam [Ditjen PHKA] (2011) Keputusan Dirjen PHKA No, SK.261/IV-KKH/2011 tanggal 30 Desember 2011 tentang Kuota Pengambilan Tumbuhan Alam dan Penangkapan Satwaliar yang Termasuk Appendix CITES Tahun 2012. PHKA, Jakarta, Indonesia.

Dickson B, Hutton J, Adams WM (eds) (2009) Recreational Hunting, Conservation and Rural Livelihoods. Oxford, UK, Wiley-Blackwell.

Di Minin E, Clements HS, Correia RA, CortésCapano G, Fink C, Haukka A, Hausmann A, Kulkarni $\mathrm{R}$, Bradshaw CJA (2021) Consequences of recreational hunting for biodiversity conservation and livelihoods. One Earth 4: 238-253.

Dounias E (2016) From Subsistence to Commercial Hunting: Technical Shift in Cynegetic Practices Among Southern Cameroon Forest Dwellers During the 20th Century. Ecology and Society 21: 1-13.

Duffy R, St John FAV, Büscher B, Brockington D (2016) Toward a new understanding of the links between poverty and illegal wildlife hunting: Poverty and Illegal Wildlife Hunting. Conservation Biology 30: 14-22.

Fa JE, Peres CA, Meeuwig J (2002) Bushmeat Exploitation in Tropical Forest: An Intercontinental Comparison. Conservation Biology 16: 232237.

Farida MY, Jumari, Muhammad F (2014) Etnozoologi Suku Anak Dalam (SAD) Kampung Kebun Duren Desa Lantak Seribu Kecamatan Renah Pamenang Kabupaten Merangin Provinsi Jambi. Jurnal Biologi 3: 29-39.

Fernandes-Ferreira H, Mendonça SV, Albano C, Ferreira FS, Alves RRN (2012) Hunting, use and conservation of birds in Northeast Brazil. Biodiversity and Conservation 21: 221-244.

Gustaman B (2019) Sisi lain Kehidupan Preangerplanters Dari Perburuan Hingga Gagasan Konservasi Satwa Liar. Patanjala 11: 235-248.

Hare B, Tomasello M (2005) Human like social skills in dogs. Trends in Cognitive Sciences 9:
$439-44$.

Herzegovina H, Kusrini MD, Masy'ud B (2019) Karakteristik dan Persepsi Masyarakat Terhadap Obat Tradisional Berbahan Herpetofauna di Jakarta dan Bandung. Media Konservasi 24: 293-302.

Hidayati M (2017) Essay Photography: Baburu Kandiak Di Minangkabau. UPT Perpustakaan ISI, Yogyakarta, Indonesia.

IUCN (2010) The IUCN Red List of Threatened Species 2010: e.T178214A7499172. [https://www. iucnredlist.org] Accessed 09 December 2019.

Heberlein TA, Serup B, Ericsson G (2008) Female Hunting Participation in North America and Europe. Human Dimensions of Wildlife 13: $443-458$.

Hierink F, Bolon I, Durso AM, Ruiz de Castañeda R, Zambrana-Torrelio C, Eskew EA, Ray N (2020) Forty-four years of global trade in CITESlisted snakes: Trends and implications for conservation and public health. Biological Conservation 248: 108601.

Kapfer JM, Munoz DJ, Tomasek T (2012) Use of wildlife detector dogs to study Eastern Box Turtle (Terrapene carolina carolina) populations. Herpetological Conservation and Biology 7: 169-175.

Kartikasari D (2008) Keanekaragaman Jenis dan Nilai Ekonomi Satwa Liar yang digunakan Sebagai Obat di Jawa Tengah. MSi thesis, Institut Pertanian Bogor, Bogor, Indoonesia.

Kasman S (2014) Fungsi Muncak dalam Aktivitas Buru Babi. Studi Kasus: Aktivitas Buru babi di Beberapa Daerah Pinggiran Kota Padang. Undergraduate thesis, Universitas Andalas, Padang, Indonesia.

Koch A, Auliya M, Schmitz A, Kuch U, Böhme W (2007) Morphological studies on the systematics of Southeast Asian water monitors (Varanus salvator complex): nominotypic populations and taxonomic overview. Mertensiella 16: $109-180$.

Koster JM and Noss A (2014) Hunting dogs and the extraction of wildlife as a resource. Freeranging dogs and wildlife conservation. Oxford University, pp. 265-285.

Koster JM (2009) Hunting dogs in the lowland Neotropics. Journal of Anthropological Research 65: 575-610.

Koster JM (2008) Hunting with dogs in 
Nicaragua: An optimal foraging approach. Current Anthropology 49:935-44.

Kusrini MD, Alford RA (2006) Indonesia's Exports of Frogs' Legs. Traffic Bull 21:13-24.

Latinne A, Saputro S, Kalengkongan J, Kowel CL, Gaghiwu L, Ransaleleh TA, Nangoy MJ, Wahyuni I, Kusumaningrum T, Safari D, Feferholtz Y, Li H, Hagan E, Miller M, Francisco L, Daszak P, Olival KJ, Pamungkas J (2020) Characterizing and quantifying the wildlife trade network in Sulawesi, Indonesia. Global Ecology and Conservation 21: e00887.

Leader-Williams N (2009) Conservation and Hunting: Friends or Foes? In: Dickson Hutton BJ, Adams WM (eds) Recreational Hunting, Conservation and Rural Livelihoods, Oxford, UK, WileyBlackwell, pp. 9-24.

Lupo K (2011) A Dog is for Hunting. In: Albarella U, Trentacoste A (eds) Ethnozooarchaeology: The Present and Past of Human-Animal Relationships Oxbow Books.

Luxmoore R, Groombridge B (1990) Asian Monitor Lizards - A Review of Distribution, Status, Exploitation and Trade for Four Selected Species. World Conservation Monitoring Centre (WCMC), Cambridge, UK, pp. 195.

Mardiastuti A, Soehartono T (2003) Perdagangan Reptil Indonesia di Pasar Internasional. In: Kusrini MD, Mardiastuti A, Harvey T (eds) Konservasi Amfibi dan Reptil di Indonesia. Prosiding Seminar Hasil Penelitian Departemen Konservasi Sumberdaya Hutan. Institut Pertanian Bogor, Bogor, Indonesia.

Martín-Delgado LM, Rengifo-Gallego JI, SánchezMartín JM (2020) Hunting in ExtremaduraProfiles of the Hunter on the Basis of His Movements. Resources 9: 46.

Marshall BM, Strine C, Hughes AC (2020) Thousands of reptile species threatened by underregulated global trade. Nature Communications 11: 4738 .

McElwee PD (2012) The gender dimensions of the illegal trade in wildlife: Local and global connections in Vietnam. In: Cruz-torres ML, McElwee P (eds) Gender and Sustainability: Lessons from Asia and Latin America Tuckson: The University of Arizona Press, pp. 71-93.

Nasi R, Taber A, Van Vliet N (2011) Empty forests, empty stomachs? Bushmeat and livelihoods in the Congo and Amazon Basins. International Forestry Review 13: 355-368.

Naranjo EJ, Guerra MM, Bodmer RE, Bolanos JE
(2004) Subsistence hunting by three ethnic groups of the Lacandon forest, Mexico. Journal of Ethnobiology 24: 233-253.

Nijman V, Shepherd CR, Mumpuni, Kate L. Sanders (2012) Over-exploitation and illegal trade of reptiles in Indonesia. Herpetological Journal 22: 83-89.

Nijman V (2015) Water monitor lizards for sale as novelty food in Java, Indonesia. Biawak 9: $28-32$.

Nijman V (2016) Perceptions of Sundanese Men Towards the Consumption of Water Monitor Lizard Meat in West Java, Indonesia. Biawak 10: $22-25$.

Nussear KE, Esque TC, Heaton JS, Cablk ME, Drake KK, Valentin C, Yee JL, Medica PA (2008) Are wildlife detector dogs or people better at finding desert tortoises (Gopherus agassizii). Herpetological Conservation and Biology 3: 103-115.

Obioha EE, Isiugo, PN, Jimoh SO, Ikyaagba E, Ngoufo R, Serge BK, Waltert M (2012) Bush Meat Harvesting and Human Subsistence Nexus in the Oban Hill Communities of Nigeria. Journal of Human Ecology 38: 49-64.

Padam S, Arvind P, Abba A (2007) House to house survey vs snowball technique for capturing material deaths in India: a search for a costeffective method. Indian Journal of Medical Research 125:550-6.

Pangau-Adam M, Noske R, Muehlenberg M (2012) Wildmeat or Bushmeat? Subsistence Hunting and Commercial Harvesting in Papua (West New Guinea), Indonesia. Human Ecology 40: 611-621.

Pattiselanno F, Mentansan G (2010) Kearifan Tradisional Suku Maybrat Dalam Perburuan Satwa Sebagai Penunjang Pelestarian Satwa. Makara, Sosial Humaniora 14: 75-82.

Pattiselanno F, Lubis MI (2014) Hunting at the Abun Regional Marine Protected Areas: A Link Between Wildmeat and Food Security. HAYATI Journal of Biosciences 21: 180-186.

Peres CA (2000) Effects of Subsistence Hunting on Vertebrate Community Structure in Amazonian Forests. Conservation Biology 14: 240-253.

Ripple WJ, Abernethy K, Betts MG, Chapron G, Dirzo R, Galetti M, Levi T, Lindsey PA, Macdonald DW, Machovina B, Newsome TM, Peres CA, Wallach AD, Wolf C, Young H (2016) Bushmeat hunting and extinction risk to the world's mammals. 
Royal Society Open Science 3: 160498.

Riley J (2002) Mammals on the Sangihe and Talaud Islands, Indonesia, and the impact of hunting and habitat loss. Oryx 36: 288-296.

Robinson JE, Griffiths RA, Fraser IM, Raharimalala J, Roberts DL, St. John FAV (2018) Supplying the wildlife trade as a livelihood strategy in a biodiversity hotspot. Ecology and Society 23: 1-21.

Rominto, Barlian E (2019) Olahraga Tradisional Buru Babi. Universitas Negeri Padang. Jurnal Patriot doi: 10.24036/patriot.v1i2.463.

Romanoff S (1984) Matses adaptations in the Peruvian Amazon. Ph.D Dissertation, Columbia University.

Sharp R, Wollscheid KU (2009) An Overview of Recreational Hunting in North America, Europe and Australia. In: Dickson B, Hutton J, Adams WM (eds) Recreational Hunting, Conservation and Rural Livelihoods, Oxford, UK, WileyBlackwell, pp. 9-24.

Scheffers BR, Oliveira BF, Lamb I, Edwards DP (2019) Global wildlife trade across the tree of life. Science 366: 71-76.

Shine R, Harlow PS, Keogh JS, Boeadi (1996) Commercial harvesting of giant lizards: the biology of water monitors, Varanus salvator, in southern Sumatra. Biological Conservation 77: 125-134.

Shine R, Harlow, PS (1998) Ecological traits of commercially harvested water monitors, Varanus salvator, in northern Sumatra. Wildlife Research 25: 437-447.

Seprianto O (2019) Modal Sosial Pada Kelom- pok Buru Babi di Nagari Lubuk Gadang Kecamatan Sangir Kabupaten Solok Selatan. Undergraduate thesis, Universitas Andalas, Padang, Indonesia.

Situngkir SVR (2009) Perdagangan dan Pemanfaatan Ular Secara Tradisional di Wilayah Bogor. Undergraduate thesis, Institut Pertanian Bogor, Bogor, Indonesia.

Smith NJH (1976) Utilization of game along Brazil's transamazon highway. Acta Amazonia 6:455-66.

Uyeda L, Iskandar E, Purbatrapsila A, Pamungkas J, Wirsing A, Kyes R (2014) Water Monitor Lizard (Varanus salvator) Satay: A Treatment for Skin Ailments in Muarabinuangeun and Cisiih, Indoneisa. Biawak 8: 35-38.

Uyeda LT (2015) The Water Monitor Lizard Varanus salvator, Behaviour, Ecology, and Human Dimensions in Banten, Indonesia. A dissertation submitted in partial fulfillment of the requirements for the degree of Doctor of Philosophy. University of Washington.

Van Vliet N, Cruz D, Quiceno-Mesa MP, Jonhson Neves de Aquino L, Moreno J, Ribeiro R, Fa J (2015) Ride, shoot, and call: wildlife use among contemporary urban hunters in Três Fronteiras, Brazilian Amazon. Ecology and Society 20: 1-12.

Received: 01 June 2021

Accepted: 29 July 2021

Published: 06 February 2022

Editor: Rômulo Alves 